\title{
Toxicity tests using developmental stages of Hormosira banksii (Phaeophyta) identify ammonium as a damaging component of secondary treated sewage effluent discharged into Bass Strait, Victoria, Australia
}

\author{
Karen Kevekordes* \\ Department of Biological Sciences, Monash University, Clayton, Victoria 3800, Australia
}

\begin{abstract}
Developing Hormosira banksii embryos, used as bioassays in toxicity studies, identified ammonium as a toxicant in secondary treated sewage effluent discharged at Boags Rocks, Victoria, Australia. Ammonium did not affect fertilization but had a significant effect on germination at $48 \mathrm{~h}$ and cell division at $72 \mathrm{~h}$ with most damage occurring in the first $48 \mathrm{~h}$. Ammonium showed a similar effect as whole effluent (when expressed as $\mathrm{mg} \mathrm{N} \mathrm{I}^{-1}$ ammonium), sampled in June, September and November 1997, on developing $H$. banksii embryos. This similarity is further confirmed with comparable $\mathrm{EC}_{50}$ (concentration causing an effect on $50 \%$ of the population tested) and LOEC (lowest observable effect concentration) values. Mean $\mathrm{EC}_{50}$ values for the ammonium bioassays were $3.19 \mathrm{mg} \mathrm{N} \mathrm{l}^{-1}$ for germination and $6.14 \mathrm{mg} \mathrm{N} \mathrm{l}^{-1}$ for cell division. The range of mean $\mathrm{EC}_{50}$ values for the 3 effluent samples were 3.15 to $5.28 \mathrm{mg} \mathrm{N} \mathrm{l}^{-1}$ for germination and 3.53 to $6.43 \mathrm{mg} \mathrm{N} \mathrm{l}^{-1}$ for cell division. These values are well below the median ammonium concentration $\left(10.28 \mathrm{mg} \mathrm{N} \mathrm{l}^{-1}\right)$ calculated for Boags Rocks due to sewage effluent discharge.
\end{abstract}

KEY WORDS: Ammonium · Bioassay $\cdot$ Hormosira banksii embryos $\cdot$ Sewage effluent $\cdot$ Toxicity tests Resale or republication not permitted without written consent of the publisher -

\section{INTRODUCTION}

The damaging effects of sewage effluent discharge on marine macroalgal assemblages are well documented. They include a decrease in species biomass, abundance and diversity, all of which ultimately contribute to a change in the structure of the macroalgal assemblage (Borowitzka 1972, Littler \& Murray 1975, Manning 1979, Munda 1982, May 1985, Tewari \& Joshi 1988, Brown et al. 1990, Roderíquez-Prieto \& Polo 1996, Smith 1996, Bellgrove et al. 1997). Large brown macroalgae, which are very visible and often dominant intertidal seaweeds, are generally susceptible to the dam-

*E-mail: karen.kevekordes@sci.monash.edu.au aging effects of sewage effluent and disappear from effluent-affected sites (Golubic 1970, Borowitzka 1972, Littler \& Murray 1975, Manning 1975, Munda 1982, Thom 1983, May 1985, Tewari \& Joshi 1988, Brown et al. 1990, Bellgrove et al. 1997). Laboratory and fieldbased studies have also shown that the early life stages of large brown algae are similarly susceptible to sewage effluent (Tewari \& Rau 1982, Ogawa 1984, Doblin \& Clayton 1995, Tegner et al. 1995, Kevekordes \& Clayton 2000) leading to their increasing use, in recent times, as ecologically relevant bioassay systems in either toxicity studies (Anderson \& Hunt 1988, Anderson et al. 1990, Burridge \& Shir 1995, Burridge et al. 1995, 1996, 1999, Gunthorpe et al. 1995, Bidwell et al. 1998) or in studies assessing the effects of pollutants (Burrows \& Pybus 1971, Hopkin \& Kain 1978, Chung \& 
Brinkhuis 1986, Andersson et al. 1992, Garman et al. 1994a,b, Andersson \& Kautsky 1996, Gledhill et al. 1997, 1999, Kevekordes \& Clayton 2000). The continued use of macroalgae in toxicity studies will add to and complement toxicity studies, which are commonly based on marine animal bioassays (e.g. Table 1 in US EPA report 1989, Table 1 in Costello \& Read 1994).

Industrial and domestic wastewater from east and south-eastern Melbourne (Victoria, Australia) is secondary treated at the Eastern Treatment Plant (ETP) at Carrum, chlorinated, conveyed along a $56 \mathrm{~km}$ pipeline and, to ensure rapid mixing in seawater, discharged below the low water mark $(1 \mathrm{~m})$ in the surf zone at Boags Rocks. Hormosira banksii (Turner) Decaisne is a southern Australasian endemic intertidal macroalga often forming extensive stands on rocky platforms. Its disappearance from Boags Rocks was documented when the outfall commenced operation in 1975 by Manning (1979) and confirmed in subsequent intertidal macroalgal surveys (Brown et al. 1990, Bellgrove et al. 1997). Recent studies (Doblin \& Clayton 1995, Kevekordes 2000) have shown that developing $H$. banksii embryos are also susceptible to sewage effluent at the median concentration occurring at Boags Rocks $(40 \%)$ and that damage is evident in zygotes $24 \mathrm{~h}$ or older (Kevekordes 2000). These studies have also identified an ecologically relevant bioassay system where development occurs as a series of welldefined events that are easily quantified (Kevekordes \& Clayton 1996) and therefore able to be used as endpoints in toxicity studies.

The aims of this current study are to assess the toxicity of sewage effluent, identify toxic components of sewage effluent and compare the effects of whole effluent with any identified toxicants in the effluent using developing Hormosira banksii embryos. Three developmental events were used as endpoints: fertilization (1 to $2 \mathrm{~h}$ ), germination (48 h) and cell division (72 h).

\section{MATERIALS AND METHODS}

Preparation of sewage effluent and seawater treatments. Artificial seawater (ASW, modified from Maier \& Calenberg 1994) was used for all experiments to avoid bacterial contamination, variability in seawater constituents, and the occurrence of endochites (Kevekordes \& Clayton 1996). ASW was made from analytical reagent (AR) grade chemicals dissolved in Milli-Q filtered water, adjusted to 34 parts per thousand salinity (\%o $\mathrm{S}$ ) and a $\mathrm{pH}$ of 7.8 to allow comparisons with other related toxicity studies (Stauber et al. 1998).

A sample of effluent was collected in acid-washed plastic containers from the effluent reuse sample point at the ETP on 11 June, 22 September and 5 November 1997. Physico-chemical analysis of the effluent was undertaken before and immediately after salinity adjustments (34\% using artificial-modified GP-2 sea salts) and, if required, $\mathrm{pH}$ adjustments $(7.8$ with $\mathrm{NaOH}$ ). Effluent was stored and transported at $4^{\circ} \mathrm{C}$ and used in toxicity tests within $72 \mathrm{~h}$ of collection (Stauber et al. 1998). Effluent was allowed to warm to 15 to $18^{\circ} \mathrm{C}$ just prior to use in toxicity tests.

All chemicals used as toxicants in the bioassays were AR grade (Table 1) and were added to ASW the evening before use. $\mathrm{NaOCl}$ was taken from a new container. Median (90th percentile) values of effluent components in the ETP 1995/1996 monitoring report, ETP 1994/Environmental Protection Agency (EPA) report for bis (2-ethylhexyl) phthalate, and the mean value for nitrate in effluent (September 1995 to May 1998, ETP data) prior to discharge, were used to calculate approximate concentrations for Boags Rocks assuming effluent is diluted to $40 \%$ (Doblin \& Clayton 1995) and is evenly mixed with seawater after discharge (Table 1). Effluent components were tested in a logarithmic concentration series. Two toxicants tested, the anionic surfactant sodium dodecyl benzene sulphonate, and the plasticizer bis (2-ethylhexyl) phthalate, were first dissolved in ethanol and added to ASW in a final ethanol concentration of $50 \mathrm{\mu l} \mathrm{l}^{-1}$ and $0.7 \mathrm{ml}$ $\mathrm{l}^{-1}$ respectively. Controls testing the addition of ethanol (without the toxicant) to ASW were not significantly different from the ASW controls. All ASW treatments were stored overnight at $4^{\circ} \mathrm{C}$ in the dark and warmed to 15 to $18^{\circ} \mathrm{C}$ just prior to use.

Copper (0.5 $\mathrm{mg} \mathrm{l}^{-1}$ ) and phenol (200 $\left.\mathrm{mg} \mathrm{l}^{-1}\right)$ were used as positive controls (Chapman 1995) for whole effluent toxicity studies and for studies testing the toxicity of individual effluent components respectively.

Collection, storage and gamete release. Hormosira banksii plants were collected from Sorrento, backbeach $\left(38^{\circ} 21^{\prime} \mathrm{S}, 144^{\circ} 43^{\prime} \mathrm{E}\right)$ located approximately $15 \mathrm{~km}$ north west of Boags Rocks. Sorrento backbeach is not affected by the effluent plume, which is dispersed south east of the outfall due to the dominant current. Plants were collected from 3 different sites for whole effluent toxicity testing in June, September, and November and from 5 different sites for studies identifying toxic components of effluent, and stored at $4^{\circ} \mathrm{C}$ in airtight plastic bags until use. Eggs were released from 6 female plants into 1 container of ASW to ensure a common gene pool for all treatments in the experiment. The suspension of eggs was filtered through a nylon mesh $(0.2 \mathrm{~mm})$ to remove debris and small animals (Kevekordes \& Clayton 1996). Sperm were released from 5 plants into 1 container of ASW, again to ensure a common gene pool for all treatments in the experiment. 
Table 1. Median (90th percentile) concentrations (conc.) of components in effluent (1995/6) prior to discharge (ETP 1995/1996 monitoring report). These were used to calculate approximate concentrations for Boags Rocks assuming effluent is diluted to $40 \%$ and is evenly mixed with seawater after discharge. Concentration of effluent components having a significant effect on bioassay endpoints, within the range tested, $\left({ }^{*}\right.$ concentrations falling within or very near the range calculated for Boags Rocks) are listed. ${ }^{a}$ Median values for effluent, ETP 1994 (EPA results). ${ }^{b} 24 \mathrm{~h}$ composite sampling program May 1996. 'Average value (September 1995 to May 1998) for effluent, ETP data

\begin{tabular}{|c|c|c|c|c|c|c|c|}
\hline \multirow[b]{2}{*}{$\begin{array}{l}\text { Effluent component } \\
\text { (form added) }\end{array}$} & \multirow[b]{2}{*}{ Unit } & \multicolumn{2}{|c|}{ Median (90th percentile) conc. } & \multirow[b]{2}{*}{$\begin{array}{l}\text { Conc. } \\
\text { range } \\
\text { tested }\end{array}$} & \multicolumn{2}{|r|}{ Significant effect measured } & \multirow[b]{2}{*}{ Endpoint } \\
\hline & & $\begin{array}{l}\text { In effluent } \\
\text { prior to } \\
\text { discharge }\end{array}$ & $\begin{array}{l}\text { Calculated } \\
\text { for Boags } \\
\text { Rocks }\end{array}$ & & Conc. & $\mathrm{p}$ & \\
\hline Toluene & $\mu \mathrm{g} \mathrm{l}^{-1}$ & $<2.0(14)$ & $0.8(5.6)$ & $0.5-16$ & 8.0 & $(F=5.299 ; \mathrm{df}=1 ; \mathrm{p}=0.050)$ & Cell wall \\
\hline Phenol & $\mu g \mathrm{l}^{-1}$ & $<2.0(13.2)$ & $0.8(5.28)$ & $0.5-16$ & & & \\
\hline Anionic surfactants & $\mathrm{mg} \mathrm{l}^{-1}$ & $0.4(0.66)$ & $0.16(0.26)$ & $0.2-6.4$ & & & \\
\hline Lauryl sulphate & & & & & $\begin{array}{l}1.6 \\
1.6 \\
0.4^{*}\end{array}$ & $\begin{array}{l}(F=22.225 ; \mathrm{df}=1 ; \mathrm{p}=0.002) \\
(F=46.318 ; \mathrm{df}=1 ; \mathrm{p}<0.001) \\
(F=5.385 ; \mathrm{df}=1 ; \mathrm{p}=0.049)\end{array}$ & $\begin{array}{l}\text { Cell wall } \\
\text { Germination } \\
\text { Cell division }\end{array}$ \\
\hline $\begin{array}{l}\text { Sodium dodecyl- } \\
\text { phenylsulphonate }\end{array}$ & & & & & $\begin{array}{l}0.4^{*} \\
1.6 \\
0.8\end{array}$ & $\begin{array}{l}(F=7.005 ; \mathrm{df}=1 ; \mathrm{p}=0.029) \\
(F=103.268 ; \mathrm{df}=1 ; \mathrm{p}<0.001) \\
(F=5.839 ; \mathrm{df}=1 ; \mathrm{p}=0.042)\end{array}$ & $\begin{array}{l}\text { Cell wall } \\
\text { Germination } \\
\text { Cell division }\end{array}$ \\
\hline $\begin{array}{l}\text { bis (2-ethylhexyl) } \\
\text { phthalate }^{\mathrm{a}}\end{array}$ & $\mu g l^{-1}$ & $38(49)$ & $15.2(19.6)$ & $2.37-76$ & & & \\
\hline $\begin{array}{l}\text { Total residual } \\
\text { chlorine }(\mathrm{NaOCl})^{b}\end{array}$ & $\mathrm{mg} \mathrm{l}^{-1}$ & 0.1 & 0.04 & $0.025-0.8$ & & & \\
\hline $\begin{array}{l}\text { Copper } \\
\left(\mathrm{CuSO}_{4} \cdot 5 \mathrm{H}_{2} \mathrm{O}\right)^{\mathrm{c}}\end{array}$ & $\mathrm{mg} \mathrm{l}^{-1}$ & $0.02(0.066)$ & $0.008(0.026)$ & 0.5 & & & \\
\hline $\begin{array}{l}\text { Ammonium as } \mathrm{N} \\
\left(\mathrm{NH}_{3} \mathrm{Cl}\right)\end{array}$ & $\mathrm{mg} \mathrm{l}^{-1}$ & $25.7(32.2)$ & $10.28(12.88)$ & $0.81-26$ & $\begin{array}{l}1.62^{*} \\
3.25^{*}\end{array}$ & $\begin{array}{l}(F=46.272 ; \mathrm{df}=1 ; \mathrm{p}<0.001) \\
(F=31.069 ; \mathrm{df}=1 ; \mathrm{p}=0.001)\end{array}$ & $\begin{array}{l}\text { Germination } \\
\text { Cell division }\end{array}$ \\
\hline $\begin{array}{l}\text { Nitrate as } \mathrm{N} \\
\left(\mathrm{NaNO}_{3}\right)^{\mathrm{c}}\end{array}$ & $\mathrm{mg} \mathrm{l}^{-1}$ & 4.3 & 1.72 & $1.075-34.4$ & & & \\
\hline $\begin{array}{l}\text { Total phosphorus } \\
\left(\mathrm{KH}_{2} \mathrm{PO}_{4}\right)\end{array}$ & $\mathrm{mg} \mathrm{l}^{-1}$ & $6.0(8.1)$ & $2.4(3.24)$ & $1.5-48$ & & & \\
\hline
\end{tabular}

Bioassay. The egg pretreatment bioassay (Kevekordes 2000) was used to assess toxicity of whole effluent and of individual effluent components. The bioassay was designed to mimic as closely as possible fertilization of Hormosira banksii eggs in the intertidal environment and avoids spurious results caused by storage of gametes, polyspermy due to a high sperm/ egg ratio (Brawley 1990) and parthenogenetic development of eggs (Clayton et al. 1998). Eggs were decanted into treatments (2000 eggs $\mathrm{ml}^{-1}$ ) and allowed to incubate for $20 \mathrm{~min}$ prior to fertilization. Sperm were added to each treatment containing eggs (ca 100 sperm egg $^{-1}$ ) within 5 min of release to ensure maximum fertilization success. Treatments were gently swirled 6 to 7 min after gamete mixing, to ensure even mixing of newly fertilized/unfertilized eggs before $10 \mathrm{ml}$ aliquots were decanted into petri dishes each containing a coverslip (used for microscope observations). Embryos were grown under Sylvania Gro-lux wide spectrum fluorescent tubes $(40 \mathrm{~W})$ with a photon irradiance of $25 \mu \mathrm{mol} \mathrm{m}{ }^{-2} \mathrm{~s}^{-1}$ on a 12:12 h light:dark cycle at $15^{\circ} \mathrm{C}$ (Kevekordes \& Clayton 1996).

The following developmental features were assessed microscopically in healthy individuals: (1) cell wall for- mation (fertilization) at 1 to $2 \mathrm{~h},(2)$ germination at $48 \mathrm{~h}$ and, (3) cell division at $72 \mathrm{~h}$ after gamete mixing. Once observations were made, the coverslip was discarded and a new petri dish used to assess the next developmental feature (Kevekordes \& Clayton 1996). The presence of a cell wall was detected with the fluorochrome, calcofluor white (Hughes \& McCully 1975). This fluorochrome was also used 1 to $2 \mathrm{~h}$ after gamete mixing in all bioassays, to indicate fertilization success (Brawley \& Bell 1987) as cell wall components are secreted soon after fertilization (Quatrano \& Stevens 1976). Experiments were aborted if fertilization success was less than $95 \%$ in the control treatment.

For each developmental stage, counts of 300 individuals/treatment for whole effluent toxicity testing and 100 individuals/treatment for testing the toxicity of effluent components were made. There were 3 replicate experiments for whole effluent toxicity testing and 5 replicate experiments for toxicity testing of individual components of effluent.

Statistical analysis. Data analysis for testing individual components of effluent was undertaken in 2 steps. Initially data was analyzed using analysis of variance (ANOVA) tested at the 0.05 significance level. If results 

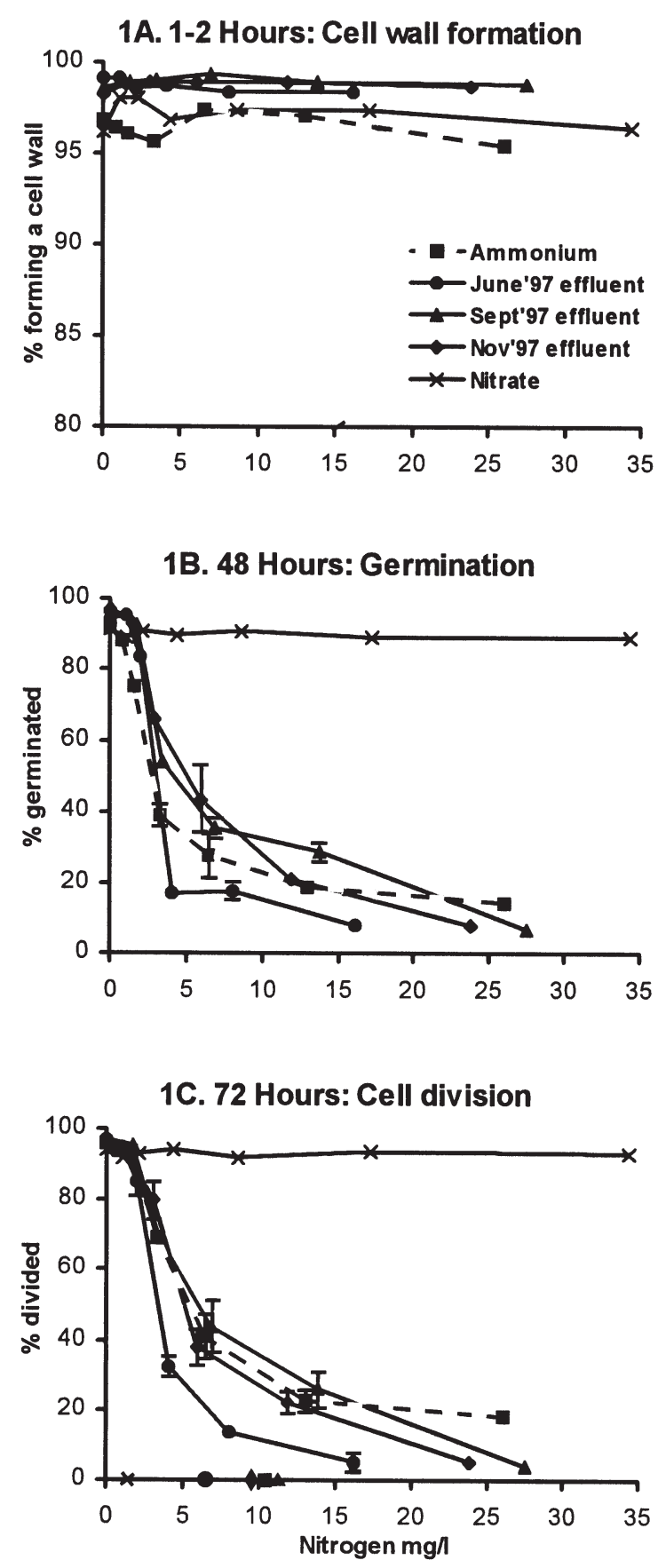

Fig. 1. Effects of ammonium, nitrate and whole effluent (represented as the measured ammonium concentration, which is plotted as the highest value for each effluent sample) on the healthy development of Hormosira banksii embryos. (A) Cell wall formation (fertilization). (B) Germination. (C) Cell division. Ammonium, nitrate, and whole effluent concentration were tested in a logarithmic concentration scale (base 2) and expressed in $\mathrm{mg} \mathrm{N}^{-1}$. Symbols on the $\mathrm{X}$-axis, corresponding to those used to plot each treatment, represent the calculated nitrogen concentration at Boags Rocks after discharge assuming a $40 \%$ dilution and even mixing in seawater for ammonium, whole effluent (as ammonium) and nitrate. Means \pm standard errors for a concentration of an effluent component, within or very near the calculated concentration range for Boags Rocks (using 90th percentile values to help indicate the range) were statistically significant from the control in any of the bioassay endpoints then data was further analyzed using Toxstat and Spearman software.

The concentration of toxicant/effluent causing an effect on $50 \%$ of the population tested $\left(\mathrm{EC}_{50}\right)$ was determined using the trimmed Spearman-Karber method (Hamilton et al. 1983) and the 'No Observed Effect Concentration' (NOEC) values were determined using Dunnett's test $(\mu=0.05)$ (Zar 1984). Percentage data was arcsin $\sqrt{ }$ transformed and tested for normality and homogeneity of variance before NOEC values were determined. Untransformed data is presented in Fig. 1 and Table 2 .

\section{RESULTS}

Within the concentration range tested, ammonium had a significant effect on 2 of the 3 developmental events (germination and cell division) assessed in Hormosira banksii but had no effect on fertilization (as determined by cell wall formation) (Table 2, Fig. 1). There was a similar trend with the effects of whole effluent (salinity adjusted) on the development of $H$. banksii embryos. Whole effluent did not affect fertilization but significantly affected subsequent embryo development (Table 2, Fig. 1). The lowest observable effect concentration (LOEC) for ammonium was $1.62 \mathrm{mg} \mathrm{N}^{-1}$ for germination and $3.25 \mathrm{mg} \mathrm{N}^{-1}$ for cell division and these concentrations were very similar to LOEC values determined for ammonium in whole effluent sampled in June, September and November 1997, which ranged from 1.72 to $2.97 \mathrm{mg} \mathrm{N} \mathrm{l}^{-1}$ for germination and 2.00 to $3.43 \mathrm{mg} \mathrm{N} \mathrm{l}^{-1}$ for cell division (Table 2).

Mean $\mathrm{EC}_{50}$ values for whole effluent sampled in June, September and November 1997 ranged from 19.23 to $21.75 \%$ for germination and 21.90 to $23.37 \%$ for cell division (Table 2). Mean $\mathrm{EC}_{50}$ values for the 3 whole effluent samples, when expressed as an ammonium concentration $\left(\mathrm{mg} \mathrm{N}^{-1}\right.$ ), were similar to $\mathrm{EC}_{50}$ values based on bioassays testing only ammonium. Mean $\mathrm{EC}_{50}$ values for the ammonium bioassays were $3.19 \mathrm{mg} \mathrm{N}^{-1}$ for germination and $6.14 \mathrm{mg} \mathrm{N}^{-1}$ for cell division (Table 2) compared with the range of mean $\mathrm{EC}_{50}$ values of 3.15 to $5.28 \mathrm{mg} \mathrm{N}^{-1}$ for germination and 3.53 to $6.43 \mathrm{mg} \mathrm{N}^{-1}$ for cell division from the 3 effluent samples (Table 2).

Variability for successful fertilization, germination and cell division in the ASW control treatments in the bioassays were low, e.g. the coefficient of variance (standard deviation as \% of mean: CV) were $<3.20 \%$ 
Table 2. Toxicity tests for ammonium ( $\mathrm{mg} \mathrm{N}^{-1}$ ) and whole effluent (\%). As ammonium levels were measured in effluent used in toxicity studies (Stauber et al. 1998) in June $\left(16 \mathrm{mg} \mathrm{N} \mathrm{l}^{-1}\right)$, September $\left(27.5 \mathrm{mg} \mathrm{N} \mathrm{l}^{-1}\right)$ and November $\left(23.8 \mathrm{mg} \mathrm{N} \mathrm{l}^{-1}\right) 1997$, the mean $\mathrm{EC}_{50}$, NOEC and LOEC values for effluent (\%) were also expressed in $\mathrm{mg} \mathrm{N}^{-1}$ ammonium. Calculated values are presented in parentheses

\begin{tabular}{|c|c|c|c|c|c|c|c|c|c|}
\hline Toxicant & $\begin{array}{l}\text { Exp } \\
\text { no. }\end{array}$ & Endpoint & $\mathrm{EC}_{50}$ & $\begin{array}{l}95 \% \text { Confidence } \\
\text { interval }\end{array}$ & $\begin{array}{l}\% \\
\text { trim }\end{array}$ & $\begin{array}{l}\text { Mean } \\
\mathrm{EC}_{50}\end{array}$ & $\begin{array}{l}\text { CV } \\
(\%)\end{array}$ & NOEC & LOEC \\
\hline \multirow{11}{*}{$\begin{array}{l}\text { Ammonium } \\
\left(\mathrm{mg} \mathrm{N} \mathrm{l}^{-1}\right)\end{array}$} & & & $\mathrm{mg} \mathrm{N} \mathrm{^{-1 }}$ & & & \multirow{6}{*}{$3.19 \mathrm{mg} \mathrm{N}^{-1}$} & \multirow{6}{*}{23.82} & \multirow{6}{*}{$0.82 \mathrm{mg} \mathrm{N} \mathrm{l}^{-1}$} & \multirow{6}{*}{$1.62 \mathrm{mg} \mathrm{N} \mathrm{l}^{-1}$} \\
\hline & 1 & Germination & 2.85 & $2.46-3.29$ & 17.50 & & & & \\
\hline & 2 & " & 4.12 & $3.29-5.17$ & 27.50 & & & & \\
\hline & 3 & $"$ & 3.76 & $3.05-4.64$ & 20.00 & & & & \\
\hline & 4 & $"$ & 3.02 & $2.54-3.59$ & 16.00 & & & & \\
\hline & 5 & $"$ & 2.19 & $1.91-2.51$ & 12.00 & & & & \\
\hline & 1 & Cell division & 4.67 & $3.91-5.59$ & 19.00 & \multirow{5}{*}{$6.14 \mathrm{mg} \mathrm{N} \mathrm{l}^{-1}$} & \multirow{5}{*}{29.80} & \multirow{5}{*}{$1.62 \mathrm{mg} \mathrm{N}^{-1}$} & \multirow{5}{*}{$3.25 \mathrm{mg} \mathrm{N} \mathrm{l}^{-1}$} \\
\hline & 2 & $"$ & 7.06 & $5.87-8.51$ & 19.00 & & & & \\
\hline & 3 & $"$ & 7.43 & $6.41-8.61$ & 18.00 & & & & \\
\hline & 4 & $"$ & 7.82 & $6.60-9.27$ & 17.00 & & & & \\
\hline & 5 & $"$ & 3.71 & $3.29-4.18$ & 18.00 & & & & \\
\hline \multirow{5}{*}{$\begin{array}{l}\text { Effluent (\%) } \\
\text { June } 97\end{array}$} & & & $\%$ & & & \multirow{3}{*}{$\begin{array}{c}19.51 \% \\
\left(3.15 \mathrm{mg} \mathrm{N} \mathrm{l}^{-1}\right)\end{array}$} & \multirow{3}{*}{8.20} & \multirow{3}{*}{\multicolumn{2}{|c|}{$\begin{array}{cc}6.25 \% & 12.5 \% \\
\left(1.00 \mathrm{mg} \mathrm{N} \mathrm{l}^{-1}\right) & \left(2.00 \mathrm{mg} \mathrm{N}^{-1}\right)\end{array}$}} \\
\hline & 1 & Germination & 21.17 & $19.95-22.47$ & 6.67 & & & & \\
\hline & $\begin{array}{l}2 \\
3\end{array}$ & $"$ & $\begin{array}{l}19.38 \\
17.97\end{array}$ & $\begin{array}{l}18.19-20.64 \\
16.86-19.16\end{array}$ & $\begin{array}{l}8.00 \\
8.67\end{array}$ & & & & \\
\hline & 1 & Cell division & 20.84 & $19.72-22.02$ & 6.33 & \multirow{2}{*}{$\begin{array}{c}21.90 \% \\
\left(3.53 \mathrm{mg} \mathrm{N} \mathrm{l}^{-1}\right)\end{array}$} & \multirow[t]{2}{*}{16.35} & \multirow{2}{*}{\multicolumn{2}{|c|}{$\begin{array}{cc}6.25 \% & 12.5 \% \\
\left(1.00 \mathrm{mg} \mathrm{N} \mathrm{l}^{-1}\right) & \left(2.00 \mathrm{mg} \mathrm{N}^{-1}\right)\end{array}$}} \\
\hline & $\begin{array}{l}2 \\
3\end{array}$ & $"$ & $\begin{array}{l}25.89 \\
18.96\end{array}$ & $\begin{array}{l}24.21-27.68 \\
17.84-20.16\end{array}$ & $\begin{array}{l}8.6 t \\
4.00\end{array}$ & & & & \\
\hline \multirow{4}{*}{$\begin{array}{l}\text { Effluent (\%) } \\
\text { September } 97\end{array}$} & 1 & Germination & 19.29 & $17.84-20.86$ & 5.67 & \multirow{2}{*}{$\begin{array}{c}19.23 \% \\
\left(5.28 \mathrm{mg} \mathrm{N} \mathrm{l}^{-1}\right)\end{array}$} & \multirow{2}{*}{0.50} & \multirow{2}{*}{\multicolumn{2}{|c|}{$\begin{array}{cc}0.5 \% & 6.25 \% \\
\left(0.14 \mathrm{mg} \mathrm{N} \mathrm{l}^{-1}\right) & \left(1.72 \mathrm{mg} \mathrm{N} \mathrm{l}^{-1}\right)\end{array}$}} \\
\hline & $\begin{array}{l}2 \\
3\end{array}$ & " & $\begin{array}{l}19.11 \\
19.28\end{array}$ & $\begin{array}{l}17.73-20.61 \\
17.50-21.25\end{array}$ & $\begin{array}{l}6.67 \\
8.00\end{array}$ & & & & \\
\hline & 1 & $\underset{\|}{\text { Cell division }}$ & $\begin{array}{l}19.46 \\
19.87\end{array}$ & $\begin{array}{l}18.11-20.92 \\
18.36-21.50\end{array}$ & 4.00 & \multirow{2}{*}{$\begin{array}{c}23.37 \% \\
\left(6.43 \mathrm{mg} \mathrm{N}^{-1}\right)\end{array}$} & \multirow[t]{2}{*}{27.47} & \multirow{2}{*}{$\begin{array}{c}6.25 \% \\
\left(1.72 \mathrm{mg} \mathrm{N} \mathrm{l}^{-1}\right)\end{array}$} & $12.5 \%$ \\
\hline & $\begin{array}{l}2 \\
3\end{array}$ & $"$ & $\begin{array}{l}19.87 \\
30.77\end{array}$ & $\begin{array}{l}18.36-21.50 \\
28.63-33.06\end{array}$ & $\begin{array}{l}2.0 t \\
5.00\end{array}$ & & & & $\left(3.43 \mathrm{mg} \mathrm{N} \mathrm{l}^{-1}\right)$ \\
\hline \multirow{4}{*}{$\begin{array}{l}\text { Effluent (\%) } \\
\text { November } 97\end{array}$} & 1 & $\underset{\text { Germination }}{\text { Germ }}$ & 21.24 & $\begin{array}{l}19.65-22.96 \\
1499-17.75\end{array}$ & 8.00 & \multirow{2}{*}{$\begin{array}{c}21.75 \% \\
\left(5.17 \mathrm{mg} \mathrm{N} \mathrm{l}^{-1}\right)\end{array}$} & \multirow[t]{2}{*}{26.25} & \multirow{2}{*}{$\begin{array}{c}6.25 \% \\
\left(1.49 \mathrm{mg} \mathrm{N} \mathrm{l}^{-1}\right)\end{array}$} & \multirow{2}{*}{$\begin{array}{c}12.5 \% \\
\left(2.97 \mathrm{mg} \mathrm{N} \mathrm{l}^{-1}\right)\end{array}$} \\
\hline & $\begin{array}{l}2 \\
3\end{array}$ & " & $\begin{array}{l}16.31 \\
27.70\end{array}$ & $\begin{array}{l}14.99-17.75 \\
25.68-29.87\end{array}$ & $\begin{array}{l}6.33 \\
8.67\end{array}$ & & & & \\
\hline & 1 & Cell division & 19.76 & $17.91-21.80$ & 4.67 & \multirow{2}{*}{$\begin{array}{c}22.70 \% \\
\left(5.40 \mathrm{mg} \mathrm{N} \mathrm{l}^{-1}\right)\end{array}$} & \multirow{2}{*}{26.04} & \multirow{2}{*}{$\begin{array}{c}6.25 \% \\
\left(1.49 \mathrm{mg} \mathrm{N}^{-1}\right)\end{array}$} & \multirow{2}{*}{$\begin{array}{c}12.5 \% \\
\left(2.97 \mathrm{mg} \mathrm{N} \mathrm{l}^{-1}\right)\end{array}$} \\
\hline & $\begin{array}{l}2 \\
3\end{array}$ & $"$ & $\begin{array}{l}18.84 \\
29.50\end{array}$ & $\begin{array}{l}17.02-20.85 \\
27.69-31.42\end{array}$ & $\begin{array}{l}7.33 \\
6.00\end{array}$ & & & & \\
\hline
\end{tabular}

for the ammonium bioassays and $<2.00 \%$ for the whole effluent bioassays. The $\mathrm{CV}$ around the mean $\mathrm{EC}_{50}$ value for ammonium and for whole effluent testing, using either germination or cell division as endpoints, were less than $30 \%$ indicating that the bioassay results are consistent when compared with limits set using known toxicants for reference testing (Gunthorpe et al. 1995 and references within).

One hour after fertilization, over $95 \%$ of zygotes in treatments containing either ammonium (26 mg N l${ }^{-1}$ ) or whole effluent (salinity adjusted) appeared healthy, had synthesized a cell wall (feature used to assess fertilization) and showed central clustering of chloroplasts (Kevekordes \& Clayton 1996) (Fig. 2). By 48 h, however, the majority of zygotes in the ammonium and effluent treatments had not germinated and some zygotes were leaking cell contents (Fig. 2). Zygotes that did germinate in these treatments were stunted compared with germinated zygotes in the control (Fig. 2).

Elevated levels of nitrogen in the form of nitrate, which were comparable to levels tested in the form of ammonium and to levels measured in the effluent samples, had no effect on any of the 3 developmental events assessed in Hormosira banksii embryos (Table 1, Fig. 1).

Of the other effluent components tested the 2 anionic surfactants, sodium lauryl sulphate and sodium dodecyl benzene sulphonate and the solvent, toluene had a significant effect on one or more endpoints assessed (fertilization, germination, cell division) within the concentration range tested. However, the concentration that had a significant effect on any of the developmental events assessed exceeded the 90th percentile concentration value calculated for Boags Rocks (Table 1). 


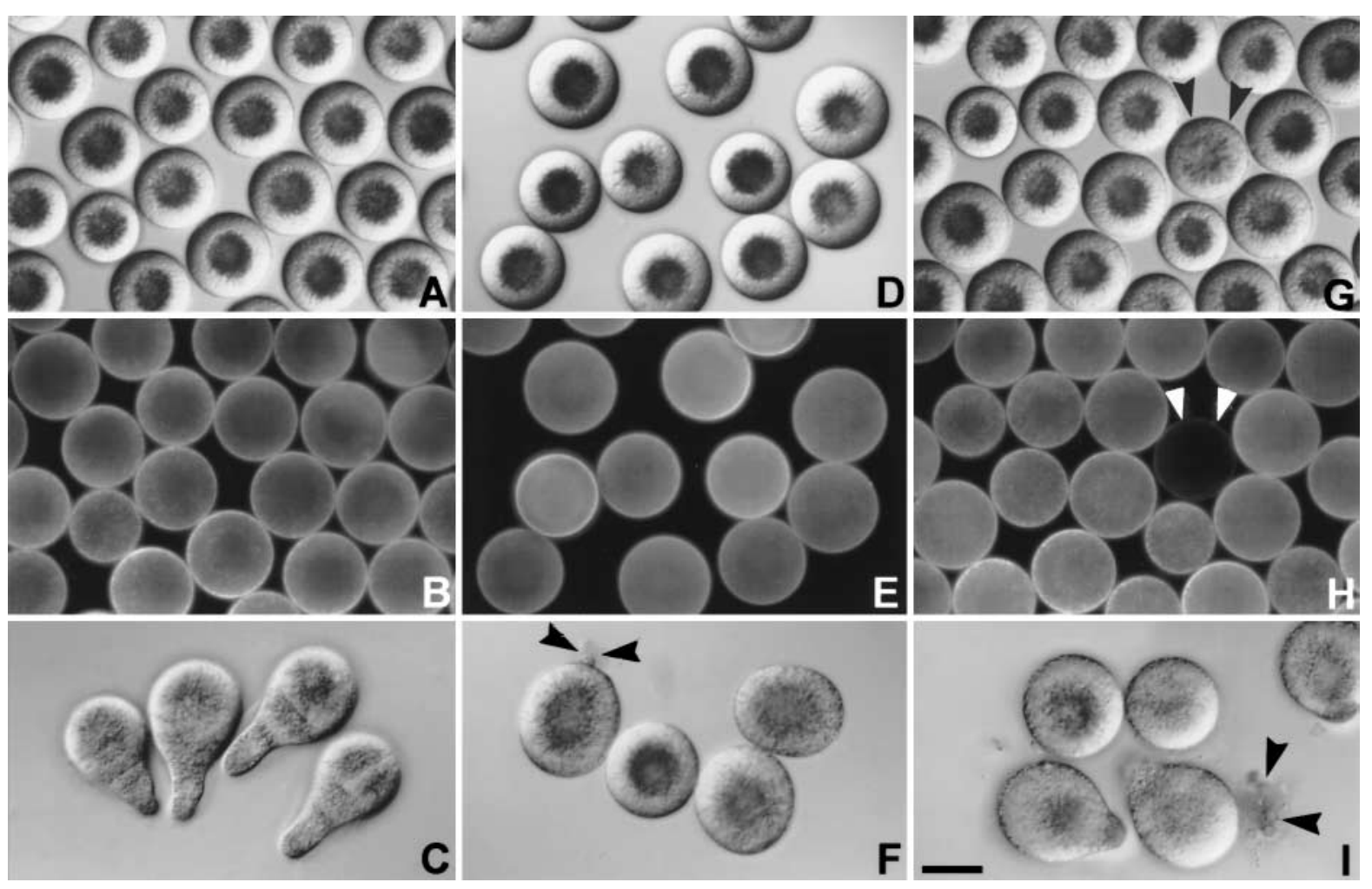

Fig. 2. Development of Hormosira banksii embryos in ASW (A,B,C), ammonium (D,E,F) and whole effluent (G,H,I). Cell wall formation 1 to $2 \mathrm{~h}$ after fertilization in $\operatorname{ASW}(A, B)$, ammonium $(D, E)$ and whole effluent $(G, H)$. Each treatment is stained with calcofluor white and viewed with differential interference contrast optics $(A, D, G)$ and epifluorescence optics with UV excitation $(B, E, H)$. Unfertilized eggs are distinguished from newly fertilized eggs by a diffuse distribution of chloroplasts (arrowed, G) and the absence of a cell wall (arrowed, H). Embryo development at $48 \mathrm{~h}$ in ASW (C), ammonium (F) and whole effluent (I). Lost cell contents arrowed $(F, I)$. Scale bar $=50 \mu \mathrm{m}$

\section{DISCUSSION}

Effluent concentrations that significantly affected post-fertilization embryo development in Hormosira banksii (6.25 to $12.5 \%$ ) and average $\mathrm{EC}_{50}$ values (19.23 to $23.37 \%$ ) for these developmental events are well below the average effluent concentration at Boags Rocks (40\%) (Doblin \& Clayton 1995). Based on this, successful recruitment of $H$. banksii at Boags Rocks would have been reduced by the damaging effects of effluent discharge on embryo development, as proposed by Doblin \& Clayton (1995), and subsequently supported in seeding experiments (Kevekordes unpubl. data). This effect would have been further compounded by the rapid disappearance of adult (fertile) H. banksii from Boags Rocks as documented by Manning (1979) and the small dispersal shadow of zygotes reported for this species (Bellgrove et al. 1997). Recruitment may have been similarly affected in Durvillaea potatorum (Labillardière) Areschoug, which has also disappeared from Boags Rocks (Manning 1979, Brown et al. 1990), as embryo development is similarly susceptible to the damaging effects of sewage effluent (Doblin \& Clayton 1995).

Of the sewage effluent components tested, ammonium appears to have the most damaging effect on the development of Hormosira banksii embryos confirming findings from an earlier study (Kevekordes \& Clayton 2000). The impact of ammonium showed a similar trend to that of whole effluent (salinity adjusted) on the development of $H$. banksii embryos with no effect on fertilization but significant effects on subsequent developmental events. The similarity between the ammonium and whole effluent effects on $H$. banksii embryo development is further confirmed with comparable $\mathrm{EC}_{50}$ and LOEC values (expressed as $\mathrm{mg} \mathrm{N}^{-1}$ ammonium) for germination and cell division. Furthermore, the impact of both ammonium and whole effluent on developing $H$. banksii embryos largely occurs by $48 \mathrm{~h}$ when germination is assessed with comparatively small changes occurring between 48 and $72 \mathrm{~h}$ after which time cell division is assessed (Kevekordes \& Clayton 2000). This is useful for confirming $\mathrm{EC}_{50}$ values derived using either endpoint. Germination, 
however, appears to be more susceptible than cell division to ammonium and to whole effluent particularly at low concentrations, which would account for differences in NOEC and LOEC values.

Ammonium is an important source of nitrogen for algae (Topinka 1978, Fujita et al. 1988) and is rapidly taken up (Haines \& Wheeler 1978, Fujita et al. 1988) because it provides an energetic advantage over the uptake and assimilation of nitrate (Turpin 1991), a more abundant source of nitrogen in coastal waters (Fujita et al. 1988). Transport of ammonium across the plasma membrane is either by active uptake of ammonium or passive diffusion of ammonia (Syrett 1988, Rees 1995). Uptake in nitrogen-replete algae is mostly by diffusion (Rees 1995, Taylor et al. 1998), which also occurs in some algae when subjected to high levels of ammonium in the external medium (D'elia \& DeBoer 1978, Haines \& Wheeler 1978, Fujita 1985). Elevated levels of ammonium are reported to be toxic to algae (Waite \& Mitchell 1972, Prince 1974, Haines \& Wheeler 1978, Peckol \& Rivers 1995), which is attributed to an uncoupling of photosynthesis (Pearson \& Stewart 1993, MacLachlin et al. 1994) by inhibiting the electron transport chain (MacLachlin et al. 1994). In addition, enzyme and membrane function may be jeopardized due to the inability of the cell to buffer protons released from ammonium assimilation (Pearson \& Stewart 1993, van Katwijk et al. 1997). Ammonium has been identified as a toxicant in sewage effluent (e.g. Prince 1974, Costello \& Gamble 1992, Peckol \& Rivers 1995) and was found to have an inhibitory effect on germling development in several species of another fucoid, Sargassum (Ogawa 1984) similar to that described in this present study for Hormosira banksii. It should be noted that seawater $\mathrm{pH}$ at Boags Rocks has decreased $(7.63 \pm 0.05)$ due to effluent discharge and therefore would not contribute to the toxic effects of elevated ammonium levels as the proportion of unionized ammonia (the more toxic form that is taken up by passive diffusion) would also decrease (Syrett 1988, US EPA report 1989, MacLachlan et al. 1994, van Katwijk et al. 1997).

In a previous study, the median concentrations for a number of heavy metals, calculated for Boags Rocks, were found not to affect development of Hormosira banksii embryos that were assessed for up to seven days (Kevekordes \& Clayton 2000). Copper, used as a reference toxicant in whole effluent testing at a concentration of $0.5 \mathrm{mg} \mathrm{l}^{-1}$, also had no effect on developing $H$. banksii embryos. This concentration greatly exceeded the copper concentration range in effluent, prior to discharge. Tolerance of heavy metals such as copper may well be due to the ongoing synthesis and secretion of the cell wall components, alginate, sulfated polysaccharides and phenolic compounds, asso- ciated with brown algal embryo development (Quatrano \& Stevens 1976, Clayton \& Ashburner 1994, Schoenwaelder \& Clayton 1998), which have an affinity for cations (Skipnes et al. 1975, Paskins-Hurlburt et al. 1978, Ragan et al. 1979, Pellegrini 1980, Lignell et al. 1982, Mariani et al. 1985, Smith et al. 1986, Karez \& Pereira 1995, Amado Filho et al. 1996, Gledhill et al. 1997). Susceptibility to the toxic effects of heavy metals, however, may be enhanced in developing $H$. banksii embryos, which are stressed due to exposure to other effluent components such as elevated levels of ammonium and to the impact of effluent discharge such as reduced salinity (Andersson \& Kautsky 1996).

While these studies have shown that ammonium is a toxic component of effluent eliciting a similar response to that of whole effluent on Hormosira banksii embryo development, these results should be treated with caution given that this is a simple laboratory-based approach. These toxicity tests, for example, do not take into account the fact that sewage effluent discharge reduces salinity to an average of $20 \%$ at Boags Rocks (Doblin \& Clayton 1995) nor do they factor in salinity variation (12.5 to $28.8 \%$ ) measured at this site (Kevekordes 2000). Osmotic-stress induced damage, caused by a reduction in salinity to $20 \%$, in developing $H$. banksii embryos occurs largely within the first $48 \mathrm{~h}$ and significantly affects fertilization, germination, cell division and adhesion (Doblin \& Clayton 1995, Kevekordes 2000, Kevekordes \& Clayton 2000). This study also does not take into account susceptibility of stressed embryos, due to either low salinity and/or elevated levels of ammonium to other components in effluent, which individually were found to be non-toxic in unstressed embryos. Osmotically stressed embryos for example, were found to be more susceptible to toxic effects of $40 \%$ effluent (Doblin \& Clayton 1995, Kevekordes 2000) and to the toxic effects of ammonium elevated to the median concentration calculated for Boags Rocks (Kevekordes \& Clayton 2000). Stressed embryos would probably also be more susceptible to high concentration pulses of toxicants such as toluene and anionic surfactants in sewage effluent, which when tested individually, were found to have a significant effect on $H$. banksii embryos development just beyond the concentration range calculated for Boags Rocks. Similarly, these toxicity studies do not indicate susceptibility of embryos, stressed through exposure to effluent, to pressures associated with the intertidal environment such as grazing and wave activity (Kevekordes unpubl. data). Furthermore, effluent composition is both variable (Stauber et al. 1998) and complicated with individual components acting synergistically to either enhance or reduce the toxic effect of a single effluent component through interactions between other effluent components and seawater con- 
stituents (Hopkin \& Kain 1978, Strömgren 1980, Garman et al. 1994a,b, Munda \& Veber 1996, Gledhill et al. 1997, Haglund 1997). Finally, this study is based on one part of a life cycle of one species, albeit an ecologically relevant species as it has disappeared from Boags Rock in response to effluent discharge (Manning 1979). Susceptibility to toxicants in sewage effluent will, however, vary not only among species but may well vary during the life of a species (Chapman 1995).

Ideally, this study should be part of a larger study using bioassays from a range of organisms preferably from taxa occurring in the disturbed region that have been identified as being susceptible to effluent discharge (Manning 1979, Brown et al. 1990). This approach would yield a more detailed toxicity assessment of sewage effluent and may also give insights into the changing ecology of the affected coastline.

Acknowledgements. The author gratefully acknowledges: R. Molloy for supplying information on effluent composition, J. Stauber for organizing a study assessing effluent toxicity for Melbourne Water in 1997, and I. Anderson and L. Gunthorpe for the preparation, analysis and delivery of effluent samples to Monash University. Helpful discussions with J. Beardall and constructive criticisms of the manuscript by A. Quigg and M. Clayton are also acknowledged. This study was jointly funded by Melbourne Water Corporation and a grant from the Australian Research Council.

\section{LITERARTURE CITED}

Amado Filho GM, Karez CS, Pfeiffer WC, Yoneshigue-Valentin Y, Farina M (1996) Accumulation, effects on growth, and localization of zinc in Padina gymnospora (Dictyotales, Phaeophyceae). Hydrobiologia 326/327:451-456

Anderson BS, Hunt JW (1988) Bioassay methods for evaluating the toxicity of heavy metals, biocides and sewage effluent using microscopic stages of giant kelp Macrocystis pyrifera (Agardh): a preliminary report. Mar Environ Res 26:113-134

Anderson BS, Hunt JW, Turpen SL, Coulon AR, Martin M (1990) Copper toxicity to microscopic stages of giant kelp Macrocystis pyrifera: interpopulation comparisons and temporal variability. Mar Ecol Prog Ser 68:147-156

Andersson S, Kautsky L (1996) Copper effects on reproductive stages of Baltic sea Fucus vesiculosus. Mar Biol 125: 171-176

Andersson S, Kautsky L, Kautsky N (1992) Effects of salinity and bromine on zygotes and embryos of Fucus vesiculosus from the Baltic Sea. Mar Biol 114:661-665

Bellgrove A, Clayton MN, Quinn GP (1997) Effects of secondarily treated sewage effluent on intertidal macroalgal recruitment processes. Mar Freshw Res 48:137-146

Bidwell JR, Wheeler KW, Burridge TR (1998) Toxicant effects on the zoospore stage of the marine macroalga Ecklonia radiata (Phaeophyta: Laminariales). Mar Ecol Prog Ser 163:259-265

Borowitzka MA (1972) Intertidal algal species diversity and the effect of pollution. Aust J Mar Freshwat Res 23:73-84

Brawley SH (1990) Polyspermy blocks in fucoid algae and the occurrence of polyspermy in nature. In: Dale B (ed)
Mechanisms of Fertilization. Springer-Verlag, Berlin, p 419-431

Brawley SH, Bell E (1987) Partial activation of Fucus eggs with calcium ionophores and low-sodium seawater. Dev Biol 122:217-226

Brown VB, Davies SA, Synnot RN (1990) Long-term monitoring of the effects of treated sewage effluent on the intertidal macroalgal community near Cape Schanck, Victoria, Australia. Bot Mar 33:85-98

Burridge TR, Karistianos M, Bidwell J (1999) The use of aquatic macrophyte ecotoxicological assays in monitoring coastal effluent discharges in Southern Australia. Mar Pollut Bull 39:89-96

Burridge TR, Shir M (1995) The comparative effects of oil dispersants and oil/dispersant conjugates on germination of the marine macroalga Phyllospora comosa (Fucales: Phaeophyta). Mar Pollut Bull 31:4-12

Burridge TR, Lavery T, Lam PKS (1995) Acute toxicity tests using Phyllospora comosa (Labillardiere) C. Aardh (Phaeophyta: Fucales) and Allorchestes compressa Dana (Crustacea: Amphipoda). Bull Environ Contam Toxicol 55:621-628

Burridge TR, Portelli T, Ashton P (1996) Effect of sewage effluents on germination of three marine brown algal macrophytes. Mar Freshw Res 47:1009-1014

Burrows EM, Pybus C (1971) Laminaria saccharina and marine pollution in north-east England. Mar Pollut Bull 2: 53-56

Chapman PM (1995) Bioassay testing for Australia as part of water quality assessment programmes. Aust J Ecol 20: 7-19

Chung IK, Brinkhuis BH (1986) Copper effects in early stages of the kelp, Laminaria saccharina. Mar Pollut Bull 17: 213-218

Clayton MN, Ashburner CM (1994) Secretion of phenolic bodies following fertilisation in Durvillaea potatorum (Durvillaeales, Phaeophyta). Eur J Phycol 29:1-9

Clayton MN, Kevekordes K, Schoenwaelder MEA, Schmid CE, Ashburner CM (1998) Parthenogenesis in Hormosira banksii (Fucales, Phaeophyceae). Bot Mar 41:23-30

Costello MJ, Gamble JC (1992) Effects of sewage sludge on embryos and larvae of marine fish. Mar Environ Res 33: 49-74

Costello MJ, Read P (1994) Toxicity of sewage sludge to marine organisms: a review. Mar Environ Res 37:23-46

D'elia CF, DeBoer JA (1978) Nutritional studies of two red algae. II. Kinetics of ammonium and nitrate uptake. J Phycol 14:266-272

Doblin MA, Clayton MN (1995) Effects of secondarily-treated sewage effluent on the early life-history stages of two species of brown macroalgae: Hormosira banksii and Durvillaea potatorum. Mar Biol 122:689-698

Fujita RM (1985) The role of nitrogen in regulating transient ammonium uptake and nitrogen storage by macroalgae. J Exp Mar Biol Ecol 92:283-301

Fujita RM, Wheeler PA, Edwards RL (1988) Metabolic regulation of ammonium uptake by Ulva rigida (Chlorophyta): a compartmental analysis of the rate-limiting step for uptake. J Phycol 24:560-566

Garman GD, Murali C, Pillai MC, Cherr GN (1994a) Inhibition of cellular events during early algal gametophyte development: effects of select metals and an aqueous petroleum waste. Aquat Toxicol 28:127-144

Garman GD, Pillai MC, Goff LJ, Cherr GN (1994b) Nuclear events during early development in gametophytes of Macrocystis pyrifera, and the temporal effects of a marine contaminant. Mar Biol 121:355-362 
Gledhill M, Nimmo M, Hill SJ, Brown MT (1997) The toxicity of copper(II) species to marine algae, with particular reference to macroalgae. J Phycol 33:2-11

Gledhill M, Nimmo M, Hill SJ, Brown MT (1999) The release of copper-complexing ligands by the brown alga Fucus vesiculosus (Phaeophyceae) in response to increasing total copper levels. J Phycol 35:501-509

Golubic S (1970) Effect of organic pollution on benthic communities. Mar Pollut Bull 1:56-57

Gunthorpe L, Nottage M, Palmer D, Wu R (1995) The development of a fertilisation inhibition assay using gametes of the brown alga Hormosira banksii. Aust J Ecotoxicol 1: $25-31$

Haglund K (1997) The use of algae in aquatic toxicity assessment. Prog Phycol Res 12:181-212

Haines KC, Wheeler PA (1978) Ammonium and nitrate uptake by the marine macrophytes Hypnea musciformis (Rhodophyta) and Macrocystis pyrifera (Phaeophyta). J Phycol 14:319-324

Hamilton MA, Russo RC, Thurston RV (1983) Trimmed Spearman-Karber method for estimating lethal concentrations in toxicity bioassays. Environ Sci Technol 11:714-718

Hopkin R, Kain JM (1978) The effects of some pollutants on the survival, growth and respiration of Laminaria hyperborea. Estuar Coast Mar Sci 7:531-553

Hughes J, McCully ME (1975) The use of an optical brightener in the study of plant structure. Stain Technol 50: 319-329

Karez CS, Pereira RC (1995) Metal contents in polyphenolic fractions extracted from the brown alga Padina gymnospora. Bot Mar 38:151-155

Kevekordes K (2000) Sewage effluent tests using early developmental stages of the brown alga, Hormosira banksii (Phaeophyta). Eur J Phycol 35:365-371

Kevekordes K, Clayton MN (1996) Using developing embryos of Hormosira banksii (Phaeophyta) as a marine bioassay system. Int J Plant Sci 157:582-585

Kevekordes K, Clayton MN (2000) Development of Hormosira banksii (Phaeophyta) embryos in selected components of secondarily treated sewage effluent. J Phycol 35:25-32

Lignell Å, Roomans GM, Pedersén M (1982) Localization of adsorbed cadmium in Fucus vesiculosus L. by X-ray microanalysis. Z Pflanzenphysiol 105:103-109

Littler MM, Murray SN (1975) Impact of sewage on the distribution, abundance and community structure of rocky intertidal macro-organisms. Mar Biol 30:277-291

MacLachlan DJ, Nugent JHA, Warden JT, Evans MCW (1994) Investigation of the ammonium chloride and ammonium acetate inhibition of oxygen evolution by photosystem II. Biochim Biophys Acta 1188:325-334

Maier I, Calenberg M (1994) Effect of extracellular $\mathrm{Ca}^{2+}$ and $\mathrm{Ca}^{2+}$-antagonists on the movement and chemioorientation of male gametes of Ectocarpus siliculosus (Phaeophyceae). Bot Acta 107:451-460

Manning PP (1979) The biological effects of discharge of secondary treated sewage effluent at Boags Rocks, Gunnamatta Beach, Victoria. MSc thesis, La Trobe University, Melbourne,

Mariani P, Tolomio C, Braghetta P (1985) An ultrastructural approach to the adaptive role of the cell wall in the intertidal alga Fucus virsoides. Protoplasma 128:208-217

May V (1985) Observations on algal floras close to two sewerage outlets. Cunninghamia 1:385-394

Munda IM (1982) The effects of organic pollution on the distribution of fucoid algae from the Istrian coast (vicinity of Rovinj). Acta Adriat 23:329-337

Munda IM, Veber M (1996) Simultaneous effects of trace met- als and excess nutrients on the Adriatic seaweed Fucus virsoides (Don.) J. Ag. (Phaeophyceae, Fucales). Bot Mar 39:297-309

Ogawa H (1984) Effects of treated municipal wastewater on the early development of sargassaceous plants. Hydrobiologia 117:389-392

Paskins-Hurlburt AJ, Skornya SC, Tanaka Y, Moore W, Stara JF (1978) Fucoidan: its binding of lead and other metals. Bot Mar 21:13-22

Pearson J, Stewart GR (1993) The deposition of atmospheric ammonia and its effects on plants. New Phytol 125: 283-305

Peckol P, Rivers JS (1995) Physiological responses of the opportunistic macroalgae Cladophora vagabunda (L) van den Hoek and Gracilaria tikvahiae (McLachlan) to environmental disturbances associated with eutrophication. J Exp Mar Biol Ecol 190:1-16

Pellegrini L (1980) Cytological studies on physodes in the vegetative cells of Cystoseira stricta Sauvageau (Phaeophyta, Fucales). J Cell Sci 41:209-231

Prince JS (1974) Nutrient assimilation and growth of some seaweeds in mixtures of seawater and secondary sewage treatment effluents. Aquaculture 4:69-79

Quatrano RS, Stevens PT (1976) Cell wall assembly in Fucus zygotes. 1. Characterization of the polysaccharide components. Plant Physiol 58:224-231

Ragan MA, Smidsrød O, Larsen B (1979) Chelation of divalent metal ions by brown algal polyphenols. Mar Chem 7: 265-271

Rees TAV (1995) On ammonium futile cycling in a marine unicellular alga. Biochim Biophys Acta 1228:254-260

Roderíquez-Prieto C, Polo L (1996) Effects of sewage pollution in the structure and dynamics of the community of Cystoseira mediterranea (Fucales, Phaeophyceae). Sci Mar 60: $253-263$

Schoenwaelder MEA, Clayton MN (1998) Secretion of phenolic substances into the zygote wall and cell plate in embryos of Hormosira and Acrocarpia (Fucales, Phaeophyceae). J Phycol 34:969-980

Skipnes O, Roald T, Haug A (1975) Uptake of zinc and strontium by brown algae. Physiol Plant 34:314-320

Smith KL, Hann AC, Harwood JL (1986) The subcellular localisation of absorbed copper in Fucus. Physiol Plant 66:692-698

Smith SD (1996) The effects of domestic sewage effluent on marine communities at Coffs Harbour, New South Wales, Australia. Mar Pollut Bull 33:309-316

Stauber J, Gunthorpe L, Anderson I, Holdway D, Gulec I, Kevekordes K (1998) Toxicity testing of Melbourne Water's Eastern Treatment Plant effluent-Final Report. CSIRO, Centre for Advanced Analytical Chemistry, Sydney

Strömgren T (1980) Combined effects of $\mathrm{Cu}$, $\mathrm{Zn}$ and $\mathrm{Hg}$ on the increase in length of Ascophyllum nodosum (L.) Le Jolis. J Exp Mar Biol Ecol 48:225-231

Syrett PJ (1988) Uptake and utilization of nitrogen compounds In: Rogers LJ, Gallons JR (eds) Biochemistry of the algae and cyanobacteria. Oxford Science, Oxford, p 23-37

Taylor RB, Peek JTA, Rees TAV (1998) Scaling of ammonium uptake by the seaweeds to surface area:volume ratio: geographical variation and the role of uptake by passive diffusion. Mar Ecol Prog Ser 169:143-148

Tegner MJ, Dayton PK, Edwards PB, Riser KL, Chadwick DB, Dean TA, Deysher L (1995) Effects of a large sewage spill on a kelp forest community: catastrophy or disturbance? Mar Environ Res 40:181-224 
Tewari A, Joshi HV (1988) Effect of domestic sewage and industrial effluents on biomass and species diversity of seaweeds. Bot Mar 31:389-397

Tewari A, Rau PS (1982) Effect of domestic sewage on the vegetative growth of juvenile plants of Sargassum johnstonii in the laboratory culture. Mahasagar-Bull Nat Inst Oceanogr 15:157-162

Thom RM (1983) Spatial and temporal patterns of Fucus distichus ssp. edentatus (de la Pyl.) Pow. (Phaeophyceae: Fucales) in Central Puget Sound. Bot Mar 26:471-486

Topinka JA (1978) Nitrogen uptake by Fucus spiralis (Phaeophyceae). J Phycol 14:241-247

Editorial responsibility: Otto Kinne (Editor), Oldendorf/Luhe, Germany
Turpin DH (1991) Effects of inorganic N availability on algal photosynthesis and carbon metabolism. J Phycol 27: $14-20$

US EPA (1989) Ambient water quality criteria for ammonia (saltwater). Office of Water, Washington, DC

van Katwijk MM, Vergeer LHT, Schmitz GHW, Roelofs JGM (1997) Ammonium toxicity in eelgrass Zostera marina. Mar Ecol Prog Ser 157:159-173

Waite T, Mitchell R (1972) The effect of nutrient fertilization on the benthic alga Ulva lactuca. Bot Mar 15:151-156

Zar JH (1984) Biostatistical analysis, 2nd edn. Prentice-Hall, Englewood Cliffs, NJ

Submitted: November 16, 2000; Accepted: March 22, 2001 Proofs received from author(s): August 2, 2001 